\title{
ANALYSIS OF FACTORS THAT INFLUENCE MANDATORY ANNUAL REPORT DISCLOSURES AT THE IDX MINING COMPANY
}

\author{
Mimelientesa $\operatorname{Irman}^{1}$, Lisa Fitrianis ${ }^{2}$ \\ Sekolah Tinggi Ilmu Ekonomi Pelita Indonesia ${ }^{1,2}$ \\ teshairman@ymail.com ${ }^{1}$
}

\begin{abstract}
ABSTRAK
Penelitian ini bertujuan untuk menguji pengaruh ukuran perusahaan, umur perusahaan, struktur kepemilikan dan profitabilitas terhadap pengungkapan wajib laporan tahunan perusahaan pertambangan. Populasi dalam penelitian ini adalah seluruh perusahaan pertambangan yang terdaftar di Bursa Efek Indonesia tahun 2013-2017 yaitu sejumlah 41 perusahaan. Pemilihan sampel dilakukan dengan metode purposive sampling dan yang terpilih sebanyak 14 perusahaan. Data yang digunakan dalam penelitian ini adalah data sekunder dengan cara mengumpulkan laporan tahunan (annual report) perusahaan dari situs Bursa Efek Indonesia yakni www.idx.co.id. Sedangkan metode analisis yang digunakan adalah uji asumsi klasik dan uji hipotesis serta analisis linear berganda. Hasil penelitian ini menunjukkan bahwa variabel ukuran perusahaan, umur perusahaan, dan profitabilitas mempunyai pengaruh terhadap pengungkapan wajib laporan tahunan, sedangkan struktur kepemilikan tidak berpengaruh terhadap pengungkapan wajib laporan tahunan. Secara simultan seluruh variabel independen dalam penelitian ini berpengaruh terhadap pengungkapan wajib laporan tahunan.
\end{abstract}

Kata Kunci : Ukuran Perusahaan, Umur Perusahaan, Struktur Kepemilikan, Profitabilitas dan Pengungkapan Wajib.

\begin{abstract}
This research aims to examine the influence of company size, company age, ownership structure and profitability on mandatory disclosures of mining company annual reports. The population in this research were all mining companies listed on the Indonesia Stock Exchange in 2013-2017, which were 41 companies. Sample selection was done by purposive sampling method and 14 selected companies were selected. The data used in this research was secondary data by collecting company annual reports from the Indonesia Stock Exchange website, www.idx.co.id. While the analytical method used are classical assumption and hypothesis testing and regression analysis. The results of this study show that the variable company size, company age, and profitability had an influence to mandatory disclosure of annual reports, while the ownership structure had not influence to mandatory disclosure of annual reports. All of independent variable in this research had an influence to mandatory disclosure of annual reports.
\end{abstract}

Keyword : Company Size, Company Age, Ownership Structure, Profitability and Mandatory Disclosure. 


\section{PENDAHULUAN}

Perekonomian Indonesia saat ini masih dilanda ketidakpastian, salah satunya dampak dari masih belum optimalnya perbaikan ekonomi dunia. Menurut laporan kebijakan moneter Bank Indonesia memandang bahwa stabilitas makro ekonomi masih terjaga, tercermin dari tingkat inflasi yang terkendali dalam kisaran sasaran tiga koma lima plus minus satu persen, defisit transaksi yang berjalan membaik, dan nilai tukar rupiah yang relatif stabil. Kendati demikian, kondisi perekonomian Indonesia serta dunia terus mengalami pergerakan dan memunculkan sejumlah fenomena. Menurut Bank Dunia pulihnya ekonomi Indonesia akan bergantung pada kebijakan untuk memperbaiki iklim usaha, menarik investasi swasta yang lebih banyak, serta diversifikasi ekonomi (Laporan Kebijakan Moneter BI Triwulan II 2018).

Sektor pertambangan di Indonesia merupakan salah satu sektor yang berpengaruh bagi pembangunan ekonomi dalam sebuah negara, disebabkan sektor ini dapat menjadi penyedia sumber daya energi seperti batubara, minyak dan gas bumi, logam dan mineral, dan batu-batuan yang sangat dibutuhkan bagi masyarakat luas dan bagi pertumbuhan ekonomi yang meningkat dan berkelanjutan. Dari masa ke masa perusahaan pertambangan semakin bertambah karena perusahaan tambang memiliki potensi yang kaya dan perusahaan semakin terbuka untuk melakukan eksplorasi sumber daya tambang tersebut.

Menurut Nordiansyah (2015) menyebutkan bahwa Direktur Utama Aberdeen, Sigit Wiryadi dalam sebuah artikel yang berjudul "Diversifikasi Sumber Dana Demi Pertumbuhan Ekonomi di 2016." Mengungkapkan, saat ini dibutuhkan diversifikasi sumber pendanaan melalui tersedianya pasar modal yang kuat, teratur, dan lancar akan berdampak positif bagi perekonomian Indonesia dan berfungsi secara efisien. Fokusnya ditekankan pada pasar utang dalam negeri yang sehat dan inklusivitas melalui peningkatan partisipasi investor domestik

Investor selaku penanam modal harus mengadakan analisa yang lebih teliti sebelum mengambil keputusan untuk melakukan investasi baru (Darmadji \& Fakhrudin, 2012). Sebelum berinvestasi, para investor hendaknya mengetahui dan memilah sahamsaham yang dapat memberikan keuntungan maksimal dari dana yang diinvestasikan. Adapun pilihan cara yang dapat digunakan investor dalam membuat keputusan investasi yaitu dengan melakukan analisis fundamental (fundamental analysis). Analisis 
fundamental adalah analisis yang dapat digunakan untuk melakukan penilaian saham yaitu dengan mempelajari dan mengamati indikator-indikator yang berhubungan dengan kondisi makro ekonomi dan kondisi industri suatu perusahaan sampai dengan indikator keuangan dan manajemen suatu perusahaan (Darmadji \& Fakhrudin, 2012). Untuk itu investor harus mengetahui terlebih dahulu kondisi kinerja suatu perusahaan yang berkaitan dengan indikator keuangan dan manajemen perusahaan yang dapat dilihat dari laporan tahunan (annual report).

Beberapa faktor yang diduga mendorong perusahaan dalam mengungkapkan informasi terkait kinerja keuangan dan manajemen perusahaan diantaranya adalah ukuran perusahaan, umur perusahaan, struktur kepemilikan, profitabilitas. Menurut Riyanto (2008), besarnya nilai equity suatu perusahaan dapat dijadikan ukuran sebuah perusahaan, seperti nilai aktiva maupun nilai penjualan. Sedangkan umur perusahaan adalah permulaan dari suatu perusahaan melakukan aktivitas opersional sehingga perusahaan tersebut dapat mempertahankan going concern serta eksistensi dalam era bisnis (Ulum, 2009). Menurut Sugiarto (2009) Struktur kepemilikan dapat diartikan sebagai struktur kepemilikan saham, yaitu dengan memperbandingan banyaknya saham yang dimiliki oleh orang dalam (insider) dengan banyanya saham yang dimiliki oleh investor. Dan Profitabilitas adalah suatu kemampuan yang dimiliki perusahaan untuk mendapatkan laba dari penjualan, total asset maupun modal sendiri (Sartono, 2012).

Pada dasarnya laporan tahunan (annual report) adalah suatu laporan yang dipublish setiap tahunnya oleh pihak perusahaan yang akan ditujukan salah satunya untuk para pemegang saham. Laporan ini berisikan keuangan dasar serta opini manajemen atas kegiatan operasi perusahaan selama setahun lalu dan bagaimana prospek perusahaan di masa yang akan datang. laporan tahunan juga menyajiakan empat laporan keuangan dasar yang terdiri dari neraca, laporan laba rugi, laporan perubahan modal, dan laporan arus kas (Brigham \& Houston, 2010).

Disclosure atau pengungkapan pada dasarnya adalah pelepasan informasi. Untuk itu perusahaan perlu mengungkapkan informasi secara lengkap dalam laporan tahunan (annual report) guna dijadikan sebagai dasar pertimbangan bagi pihak-pihak yang berkepentingan. Suwardjono (2014) menyatakan bahwa Informasi yang diungkapkan dalam laporan tahunan emiten dapat dikelompokkan menjadi dua yaitu pengungkapan wajib (mandatory disclosure) dan pengungkapan sukarela (voluntary disclosure). 
Kelengkapan pengungkapan wajib laporan tahunan ini diukur dengan suatu indeks pengungkapan (disclosure) yang berdasarkan peraturan Otoritas Jasa Keuangan nomor 29/POJK.04/2016 mengenai pengungkapan wajib laporan tahunan yang secara garis besar dibagi menjadi beberapa indikator diantaranya ikhtisar data keuangan penting, informasi saham (jika ada), laporan direksi, laporan dewan komisaris, profil emiten atau perusahaan publik, analisis dan kegiatan manajemen, perusahaan public atau tata kelola emiten, tanggung jawab lingkungan dan sosial emiten atau perusahaan publik, laporan keuangan tahunan yang selesai diaudit, dan surat pernyataan dari anggota direksi dan anggota dewan komisaris mengenai tanggung jawab atas laporan tahunan.

Namun realitanya masih banyak perusahan go public yang tidak melakukan pengungkapan sesuai standar minimal yang diwajibkan. Salah satu kasus yang pernah terjadi yaitu PT TIL yang tidak melakukan public expose atas asal-usul bahan bakunya yang telah di ekspor. Seperti diketahui, anak perusahaan PT CKRA Tbk, yakni PT Takaras Inti Lestari (TIL), pada bulan Agustus 2016 lalu telah mengekspor Zr sebanyak 400 ton. Menurut Direktur Utama Indonesia Resources Studies (IRESS), Marwan Batubara, PT TIL ini telah mengekspor hasil tambang yang ilegal karena tidak berasal dari lahan yang mempunyai izin, bahkan area penambangannya tidak dilengkapi sertifikat Clear and Clean (C\&C). Seharusnya otoritas bursa meminta perusahaan public seperti PT.Cakra Mineral (CKRA) Tbk untuk melakukan public expose dan memberi penjelasan sumber bahan baku Zirconium (Zr) yang telah mereka expor. Hal ini dikarenakan dapat merugikan negara dengan melakukan ekspor sumber daya mineral tanpa melalui prosedur yang jelas. Dalam (www.nusantaranews.co.id, 2016) Marwan juga menyampaikan perusahaan tambang yang tidak memiliki izin menambang di suatu daerah tertentu dapat membahayakan lingkungan. Didukung oleh Ketua Komisi VII DPR RI Gus Irawan Pasaribu yang menyatakan hal senada yaitu Sebagai perusahaan terbuka (Tbk), maka segala sesuatu harus dilaksanakan secara terbuka dan sesuai aturan. Kasus yang terjadi terhadap PT Takaras Inti Lestari (TIL) ini menunjukkan pentingnya pengungkapan wajib laporan tahunan.

Beberapa penelitian terdahulu yang berkaitan dengan penelitian ini sudah pernah dilakukan diantaranya oleh Efrata \& Sherlita (2012) mengenai analisis faktor-faktor yang mempengaruhi tingkat keluasan pengungkapan informasi dalam laporan tahunan. 
Hasil penelitiannya menunjukan bahwa secara simultan faktor likuiditas, solvabilitas, profitabilitas dan ukuran perusahaan memiliki pengaruh yang signifikan terhadap indeks disclosure. Selain itu secara parsial faktor profitabilitas, solvabilitas dan ukuran perusahaan berpengaruh positif terhadap tingkat keluasan pengungkapan informasi dalam laporan tahunan, sedangkan likuiditas menunjukkan pengaruh negatif.

Penelitian yang dilakukan oleh Maryam, (2012) menunjukan bahwa secara simultan dan parsial profitabilitas, ukuran perusahaan dan struktur kepemilikan berpengaruh terhadap keberadaan pengungkapan laporan tahunan. Retnoningsih (2013) dengan hasil penelitiannya menunjukkan bahwa leverage, likuiditas, profitabilitas, umur perusahaan, ukuran perusahaan, status perusahaan dan porsi saham publik secara bersama-sama berpengaruh terhadap luas pengungkapan laporan tahunan.

\section{KAJIAN TEORI}

\section{Ukuran Perusahaan}

Menurut Sugiono \& Jogi (2013) ukuran perusahaan dapat terbagi dalam 3 kriteria yaitu perusahaan besar (large firm), perusahaan menengah (medium-size) dan perusahaan kecil (small firm). Berdasarkan pasal 3 ayat 1,2, dan 3 dari Peraturan Menteri Perdagangan Republik Indonesia tanggal 16 september 2009 No.46/MDAG/PER/9/2009 yang mulai diberlakukan efektif sejak tanggal 1 juli 2010, bahwa perusahaan diklasifikasikan sebagai berikut : (1) Klasifikasi perusahaan kecil, adalah untuk perusahaan dengan kekayaan bersih lebih dari Rp.50.000.000, sampai dengan maksimum Rp.500.000.000, tidak termasuk tanah dan bangunan tempat usaha. Dan omzet lebih dari Rp. 300.000 .000 - Rp. 2.500.000.000. (2) Klasifikasi perusahaan menengah, adalah untuk perusahaan dengan kekayaan bersih lebih dari Rp. 500.000.000 sampai dengan maksimum Rp.10.000.000.000, tidak termasuk tanah dan bangunan tempat usaha. Dan omzet lebih dari Rp. 2.500.000.000 - Rp. 50.000.000.000. (3) Klasifikasi perusahaan besar, adalah untuk perusahaan dengan kekayaan bersih lebih dari Rp. 10.000.000.000, tidak termasuk tanah dan bangunan tempat usaha. Dan omzet di atas Rp. 50.000.000.000. 


\section{Umur Perusahaan}

Menurut Syafi'i (2013) menyebutkan bahwa umur perusahaan yaitu seberapa lama suatu perusahaan mampu untuk bertahan, bersaing, dan mengambil kesempatan bisnis yang ada dalam perekonomian. Menurut Ulum (2009) menyebutkan bahwa umur suatu perusahaan merupakan bagian dari dokumentasi yang menunjukkan tentang apa yang tengah terjadi dan apa yang akan diraih perusahaan.

\section{Struktur Kepemilikan}

Menurut Sudana (2011) menyebutkan bahwa struktur kepemilikan merupakan pemisahan antara pemilik perusahaan dan manajer perusahaan. Pemilik atau pemegang saham adalah pihak yang menyertakan modal ke dalam perusahaan, sedangkan manajer adalah pihakyang ditunjuk pemilik dan diberi kewengangan mengambil keputusan dalam mengelola perusahaan, dengan harapan manajer bertindak sesuai dengan kepentingan pemilik. Struktur kepemilikan terdiri dari beberapa, salah satunya adalah kepemilikan publik (Sugiarto, 2009). Kepemilikan publik adalah proporsi atau jumlah kepemilikan saham yang dimiliki oleh publik atau masyarakat umum yang tidak memiliki hubungan istimewa dengan perusahaan (Wijayanti, 2009).

\section{Profitabilitas}

Menurut Kasmir (2014) menyebutkan bahwa profitabilitas merupakan rasio untuk menilai kemampuan perusahaan dalam mencari keuntungan. Rasio ini juga dapat memberikan ukuran efekifitas manajemen suatu perusahaan. Dapat ditunjukan dari laba yang dihasilkan, dari penjulan maupun pendapatan investasi. Pada dasarnya penggunaan rasio ini dapat menunjukan efisiensi perusahaan.

\section{METODE PENELITIAN}

Penelitian ini mengambil data perusahaan-perusahaan pertambangan yang terdaftar di Bursa Efek Indonesia yang diperoleh dari situs resmi Bursa Efek Indonesia (www.idx.co.id). Waktu yang dibutuhkan dalam melakukan penelitian ini adalah sekitar enam bulan yaitu terhitung dari bulan Agustus 2018 sampai dengan bulan Januari 2019. 
Populasi dalam penelitian ini adalah perusahaan-perusahaan pertambangan yang sahamnya listing di Bursa Efek Indonesia pada periode tahun 2013 sampai 2017 yaitu sebanyak 41 perusahaan pertambangan. Pemilihan tahun 2013 sampai dengan 2017 dilakukan agar dapat diperoleh data yang relatif baru.

Teknik penarikan sampel dilakukan dengan metode purposive sampling, artinya populasi yang dijadikan sampel penelitian adalah populasi yang memenuhi kriteria sampel tertentu sesuai tujuan penelitian. Adapun kriteria yang dimaksud dalam penelitian ini adalah : (1) Perusahaan pertambangan yang sudah terdaftar di bursa efek indonesia pada tahun 2013-2017. (2) Perusahaan yang mempublikasikan laporan tahunannya lengkap di bursa efek indonesia tahun 2013-2017. (3) Perusahaan yang tidak mengalami kerugian di tahun 2013-2017.

Jenis dan data yang digunakan dalam penelitian ini adalah data sekunder, yaitu berupa laporan tahunan perusahaan sampel. Sedangkan sumber data dalam penelitian ini adalah publikasi laporan tahunan masing-masing perusahaan yang listing di BEI tahun 2013-2017 yang dapat diperoleh dari dengan mengakses situs resmi Bursa Efek Indonesia (www.idx.co.id) atau website perusahaan.

Analisis regresi linear berganda bertujuan untuk memprediksi nilai dari variabel tergantung apabila nilai variabel bebas mengalami kenaikan atau penurunan dan untuk mengetahui arah hubungan antara variabel Y dengan X (Duwi Priyatno, 2013). Dalam penelitian ini teknik analisis data menggunakan regresi linier berganda, yaitu teknik analisis untuk mengetahui pengaruh variabel independen terhadap variabel dependen. Model dalam penelitian ini adalah :

$$
\mathrm{Y}=\alpha+\beta 1 \mathrm{X} 1+\beta 2 \mathrm{X} 2+\beta 3 \mathrm{X} 3+\beta 4 \mathrm{X} 4+\mathrm{e}
$$

$$
\begin{aligned}
& \text { Keterangan : } \\
& \begin{array}{ll}
\mathrm{Y} & =\text { Pengungkapan Wajib } \\
\alpha & =\text { Konstanta } \\
\beta 1-\beta 4 & =\text { Koefisien Regresi } \\
\mathrm{X} 1 & =\text { Ukuran perusahaan } \\
\mathrm{X} 2 & =\text { Umur perusahaan } \\
\mathrm{X} 3 & =\text { Struktur kepemilikan } \\
\mathrm{X} 4 & =\text { Profitabilitas } \\
\mathrm{e} & =\text { Standart error }
\end{array}
\end{aligned}
$$




\section{HASIL PENELITIAN}

\section{Analisis Regresi Linear Berganda}

Analisis regresi berganda dalam penelitian ini digunakan untuk mengetahui pengaruh variabel independen terhadap variabel dependen. Analisis regresi berganda dilakukan dengan menggunakan program SPSS. Berikut hasil olahan regresi:

Coefficients $^{\mathrm{a}}$

Tabel 1 Hasil Analisis Regresi Berganda

\begin{tabular}{llll}
\hline \multirow{2}{*}{ Model } & \multicolumn{2}{c}{ Unstandardized Coefficients } \\
\cline { 2 - 4 } 1 & (Constant) & -.066 & Std. Error \\
\hline & UKURAN PERUSAHAAN & .051 & .010 \\
\hline & UMUR PERUSAHAAN & .004 & .001 \\
\hline & STRUKTUR KEPEMILIKAN & -.063 & .112 \\
\hline & PROFITABILITAS & .204 & .089 \\
\hline
\end{tabular}

a. Dependent Variable: PENGUNGKAPAN WAJIB

Sumber: Output SPSS

Berdasarkan hasil yang terdapat pada tabel 1 maka dapat dirumuskan persamaan regresi linear berganda sebagai berikut:

$$
\mathrm{MD}=-0,066+0,051 \text { LnSize }+0,004 \text { Age }-0,063 \text { Publik }+0,204 \mathrm{ROI}+0,167
$$

Angka-angka yang dihasilkan dari model diatas dapat dijelaskan sebagai berikut: (1) Jika tidak ada ukuran perusahaan, umur perusahaan, struktur kepemilikan, dan profitabilitas maka pengungkapan wajib adalah sebesar -0,066. (2) Nilai koefisien ukuran perusahaan (LnSize) adalah sebesar 0,051 menunjukkan hasil yang positif yang berarti setiap peningkatan ukuran perusahaan atau penambahan total aset perusahaan pertambangan sebesar 1\%, akan meningkatkan pengungkapan wajib (MD) sebesar 0,051 kali dengan asumsi variabel lain dalam persamaan regresi tetap. (3) Nilai koefisien umur perusahaan (Age) adalah sebesar 0,004 menunjukkan hasil yang positif yang berarti setiap kenaikan atau penambahan umur perusahaan pertambangan sebesar 1\%, maka akan meningkatkan pengungkapan wajib (MD) sebesar 0,004 kali dengan asumsi variabel lain dalam persamaan regresi tetap. (4) Nilai koefisien struktur kepemilikan (publik) adalah sebesar -0,063 menunjukkan hasil yang negatif yang berarti setiap kenaikan atau penambahan struktur kepemilikan pertambangan sebesar $1 \%$, maka pengungkapan wajib (MD) akan menurun sebesar 0,063 kali dengan asumsi variabel lain dalam persamaan regresi tetap. (5) Nilai koefisien profitabilitas (ROI) adalah 
sebesar 0,204 menunjukkan hasil yang positif yang berarti setiap kenaikan atau penambahan profitabilitas pertambangan sebesar 1\%, maka akan meningkatkan pengungkapan wajib (MD) sebesar 0,204 kali dengan asumsi variabel lain dalam persamaan regresi tetap.

\section{Uji F}

Uji F dilakukan untuk menguji secara keseluruhan pengaruh variabel bebas ukuran perusahaan, umur perusahaan, struktur kepemilikan, dan profitabilitas terhadap variabel terikat pengungkapan wajib. Hasil uji $\mathrm{F}$ dapat dilihat pada tabel berikut:

ANOVA $^{b}$

Tabel 2 Hasil Uji F

\begin{tabular}{|c|c|c|c|c|c|c|}
\hline \multicolumn{2}{|c|}{ Model } & \multirow{2}{*}{$\begin{array}{l}\text { Sum of Squares } \\
.470\end{array}$} & \multirow{2}{*}{$\frac{\text { df }}{4}$} & \multirow{2}{*}{$\begin{array}{l}\text { Mean Square } \\
.118\end{array}$} & \multirow{2}{*}{$\frac{F}{9.431}$} & \multirow{2}{*}{$\begin{array}{l}\text { Sig. } \\
.000^{\mathrm{a}}\end{array}$} \\
\hline 11 & Regression & & & & & \\
\hline & Residual & .810 & 65 & .012 & & \\
\hline & Total & 1.280 & 69 & & & \\
\hline
\end{tabular}

a. Predictors: (Constant), PROFITABILITAS, UKURAN PERUSAHAAN, STRUKTUR KEPEMILIKAN, UMUR PERUSAHAAN

b. Dependent Variable: PENGUNGKAPAN WAJIB

Sumber: Output SPSS

Berdasarkan uji F pada F tabel, didapati bahwa nilai $\mathrm{F}$ tabel sebesar 2,51. Karena nilai $\mathrm{F}$ hitung 9,431 lebih besar dari nilai $\mathrm{F}$ tabel sebesar 2,51, maka dapat ditarik kesimpulan bahwa variabel bebas (ukuran perusahaan, umur perusahaan, struktur kepemilikan, profitabilitas) secara simultan berpengaruh terhadap pengungkapan wajib. Berdasarkan uji F signifikansi, didapati bahwa nilai signifikansi sebesar 0,000. Karena nilai signifikansi $0,000<0,05$, sesuai dengan dasar pengambilan keputusan dalam uji $\mathrm{F}$ maka dapat disimpulkan pula bahwa (ukuran perusahaan, umur perusahaan, struktur kepemilikan, profitabilitas) secara simultan berpengaruh terhadap pengungkapan wajib.

\section{Uji Koefisien Determinasi $\left(\mathbf{R}^{2}\right)$}

Uji ini bertujuan untuk mengukur seberapa jauh kemampuan model dalam menerangkan variabel-variabel terikat. Koefisien determinasi $\left(R^{2}\right)$ menunjukkan proporsi yang diterangkan oleh variabel independen dalam model terhadap variabel terikatnya, sisanya dijelaskan oleh variabel lain yang tidak dimasukkan dalam model, 
formulasi model yang keliru dan kesalahan eksperimen. Berikut dilampirkan hasil olahan spss:

Model Summary ${ }^{b}$

Tabel 3. Hasil Uji Koefisien Determinasi

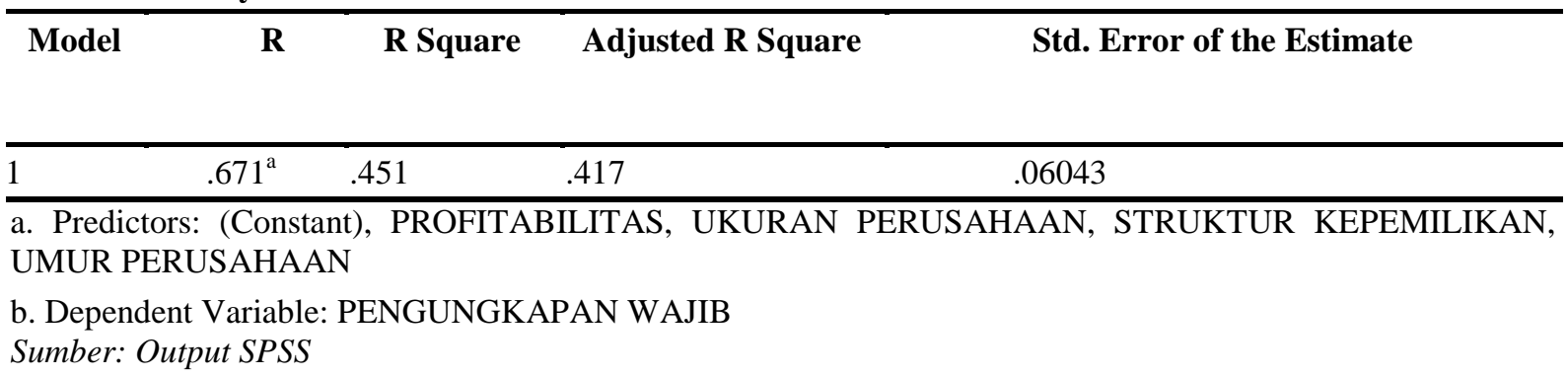

Berdasarkan tabel 3 dapat diketahui bahwa nilai Adjusted $R$ Square yang diperoleh sebesar 41,7\%. Ini berarti bahwa pengungkapan wajib (Mandatory Disclosure) perusahaan pertambangan yang terdaftar di BEI tahun 2013-2017 dapat dijelaskan oleh variabel bebasnya yaitu ukuran perusahaan, umur perusahaan, struktur kepemilikan, profitabilitas sebesar $41,7 \%$. Sisanya $58,3 \%$ dijelaskan oleh variabel lain di luar model yang tidak dimasukkan dalam penelitian.

\section{Uji Hipotesis (Uji t)}

Uji hipotesis (Uji t) dalam penelitian ini untuk menguji pengaruh ukuran perusahaan, umur perusahaan, struktur kepemilikan, profitabilitas terhadap variabel terikat pengungkapan wajib pada perusahaan pertambangan yang terdaftar di BEI tahun 2013-2017. Uji t dilakukan dengan membandingkan antara nilai signifikansi yang dihasilkan dari perhitungan statistik dengan nilai ketentuan signifikansi 5\% $(0,05)$. Untuk mengetahui nilai signifikansi dapat dilihat melalui berikut ini:

Tabel 4. Hasil Uji Hipotesis (Uji t)

\section{Coefficients $^{\mathrm{a}}$}

\begin{tabular}{|c|c|c|c|c|c|}
\hline Model & & $\mathbf{t}_{\text {hitung }}$ & $\mathbf{t}_{\text {tabel }}$ & Sig. & Keterangan \\
\hline \multirow[t]{5}{*}{1} & (Constant) & -.394 & & .695 & \\
\hline & UKURAN PERUSAHAAN & 4.908 & 1.997 & .000 & Berpengaruh signifikan \\
\hline & UMUR PERUSAHAAN & 3.452 & 1.997 & .001 & Berpengaruh signifikan \\
\hline & STRUKTUR KEPEMILIKAN & -.560 & 1.997 & .577 & Tidak berpengaruh signifikan \\
\hline & PROFITABILITAS & 2.289 & 1.997 & .025 & Berpengaruh signifikan \\
\hline
\end{tabular}

a. Dependent Variable: PENGUNGKAPAN WAJIB 
Berdasarkan dari tabel 4 uji hipotesis diatas, hipotesis pertama dalam penelitian ini adalah ukuran perusahaan berpengaruh terhadap pengungkapan wajib laporan tahunan pada perusahaan pertambangan periode 2013-2017. Hasil penelitian ini menunjukkan bahwa nilai Signifikansi variabel ukuran perusahaan sebesar 0,000 < 0,05. Hal ini berarti $\mathrm{H}_{0}$ ditolak dan $\mathrm{H}_{1}$ diterima dimana ukuran perusahaan berpengaruh terhadap pengungkapan wajib laporan tahunan pada perusahaan pertambangan periode 2013-2017.

Hipotesis kedua adalah umur perusahaan berpengaruh terhadap pengungkapan wajib laporan tahunan pada perusahaan pertambangan periode 2013-2017. Hasil penelitian ini menunjukkan bahwa nilai Signifikansi variabel umur perusahaan sebesar $0,001<0,05$. Hal ini berarti $\mathrm{H}_{0}$ ditolak dan $\mathrm{H}_{2}$ diterima dimana umur perusahaan berpengaruh terhadap pengungkapan wajib laporan tahunan pada perusahaan pertambangan periode 2013-2017.

Hipotesis ketiga adalah struktur kepemilikan berpengaruh terhadap pengungkapan wajib laporan tahunan pada perusahaan pertambangan periode 20132017. Hasil penelitian ini menunjukkan bahwa nilai Signifikansi variabel struktur kepemilikan sebesar 0,577 >0,05. Hal ini berarti $\mathrm{H}_{0}$ diterima dan $\mathrm{H}_{3}$ ditolak dimana struktur kepemilikan tidak berpengaruh terhadap pengungkapan wajib laporan tahunan pada perusahaan pertambangan periode 2013-2017.

Hipotesis keempat adalah profitabilitas berpengaruh terhadap pengungkapan wajib laporan tahunan pada perusahaan pertambangan periode 2013-2017. Hasil penelitian ini menunjukkan bahwa nilai Signifikansi variabel profitabilitas sebesar 0,025 $<0,05$. Hal ini berarti $\mathrm{H}_{0}$ ditolak dan $\mathrm{H}_{4}$ diterima dimana profitabilitas berpengaruh terhadap pengungkapan wajib laporan tahunan pada perusahaan pertambangan periode 2013-2017.

\section{PEMBAHASAN}

\section{Pengaruh Ukuran Perusahaan terhadap Pengungkapan Wajib Laporan Tahunan}

Menurut Brigham \& Houston, (2010) menyatakan ukuran perusahaan merupakan ukuran besar kecilnya sebuah perusahaan yang ditunjukan atau dinilai oleh total asset, total penjualan, jumlah laba, beban pajak dan lain-lain. Ukuran perusahaan dipandang penting karena besarnya ukuran suatu perusahaan, maka "daya jual" sebuah 
perusahaan akan lebih membaik. Para stakeholder akan menganggap perusahaan besar akan lebih tahan dari badai finansial.

Perusahaan besar akan lebih banyak disorot oleh pasar maupun publik umum dibandingkan dengan perusahaan kecil. Perusahaan besar tentunya memiliki sumber daya manusia yang sangat memadai didalamnya. Adanya sumber daya manusia yang memadai dalam suatu perusahaan, menunjukkan bahwa perusahaan mampu membiayai penyediaan informasi untuk keperluan internal. Informasi tersebut dapat pula digunakan sebagai penyedia informasi untuk keperluan eksternal.

Hasil penelitian menunjukkan ukuran perusahaan berpengaruh terhadap pengungkapan wajib laporan tahunan pada perusahaan pertambangan periode 20132017. Penelitian ini sesuai dengan penelitian yang dilakukan oleh Nugroho (2011) dimana ukuran perusahaan berpengaruh positif signifikan terhadap tingkat keluasan pengungkapan informasi dalam laporan keuangan tahunan perusahaan. Akan tetapi penelitian ini tidak sesuai dengan penelitian yang dilakukan oleh Takhtaei dan Mousavi (2012) dimana ukuran perusahaan berpengaruh negatif pada tingkat pengungkapan laporan keuangan. Jadi semakin besar ukuran perusahaan, maka hendaknya semakin luas pula pengungkapan wajib laporan tahunan yang dilakukan.

\section{Pengaruh Umur Perusahaan terhadap Pengungkapan Wajib Laporan Tahunan}

Menurut Rahmawati, (2012) menyatakan keeksisan dan kempuan suatu perusahaan dapat bersaing dapat dilihat dari umur perusahaan. Dengan data mengenai umur perusahaan, maka akan dapat memberi gambaran sejauh mana perusahaan tersebut dapat survive. Dengan arti kata semakin panjang umur perusahaan akan memberikan informasi keuangan lebih luas dibandingkan dengan perusahaan yang umurnya lebih pendek karena perusahaan tersebut tentunya memiliki pengalaman lebih banyak dalam pengungkapan laporan tahunan. Pernyataan ini dikarenakan perusahaan tersebut lebih mengetahui apa yang dibutuhkan oleh penggunanya dan informasi yang lebih detail mengenai perusahaan yang harus transparan dan dapat disajikan kepada pihak-pihak di luar manajemen yang berkepentingan terhadap perusahaan.

Umur perusahaan dapat mencerminkan seberapa besar perusahaan tersebut. Seberapa besar suatu perusahaan dapat digambarkan dalam kedewasaan perusahaan. (Gayatri \& Saputra, 2013) menyatakan kedewasaan perusahaan akan membuat 
perusahaan yang bersangkutan memahami apa yang diinginkan oleh stakeholder dan shareholdernya. Jadi semakin tinggi umur perusahaan, maka semakin tinggi pula pengungkapan wajib laporan tahunan.

Hasil penelitian menunjukkan umur perusahaan berpengaruh terhadap pengungkapan wajib laporan tahunan pada perusahaan pertambangan periode 20132017. Penelitian ini sesuai dengan penelitian yang dilakukan oleh Arif (2006) menyatakan bahwa umur perusahaan mempengaruhi kelengkapan pengungkapan laporan keuangan. Akan tetapi penelitian ini tidak sesuai dengan penelitian yang dilakukan oleh Bhayani (2012) yang mendapatkan hasil bahwa umur perusahaan berpengaruh negatif pada kelengkapan pengungkapan wajib. Jadi semakin tinggi umur perusahaan, maka semakin luas pula pengungkapan wajib laporan tahunan yang dilakukan.

\section{Pengaruh Struktur Kepemilikan terhadap Pengungkapan Wajib Laporan Tahunan}

Perbedaan dalam proporsi saham yang dimiliki investor dapat mempengaruhi tingkat kelengkapan pengungkapan oleh perusahaan karena semakin banyak investor yang tergabung dalam perusahaan akan semakin besar pula permintaan untuk mengungkapkan informasi laporan tahunan yang lebih detail sehingga perusahaan akan mengungkapkan laporan tahunan lebih lengkap untuk memenuhi permintaan investor.

Hasil penelitian menunjukkan struktur kepemilikan tidak berpengaruh signifikan terhadap pengungkapan wajib laporan tahunan pada perusahaan pertambangan periode 2013-2017. Penelitian ini tidak sesuai dengan penelitian yang dilakukan oleh Maryam (2012) yang menyatakan bahwa struktur kepemilikan berpengaruh positif terhadap keberadaan pengungkapan laporan tahunan. Tetapi penelitian ini sesuai dengan teori yang dikemukakan oleh Azaria (2014) yang berpendapat bahwa perusahaan memikirkan biaya pengungkapan yang timbul dan juga mementingkan efisiensi biaya pengungkapan sehingga perusahaan tidak bergantung pada tingkat struktur kepemilikan. Apabila semakin banyak informasi yang diungkapan perusahaan maka semakin banyak pula biaya yang timbul dari pengungkapan informasi tersebut. Jadi semakin tinggi struktur kepemilikan tidak menjamin terjadinya peningkatan pengungkapan wajib laporan tahunan yang dilakukan. 


\section{Pengaruh Profitabilitas terhadap Pengungkapan Wajib Laporan Tahunan}

Menurut Murcia \& Santos, (2010) menyatakan perusahaan yang berkinerja bagus, yang salah satunya dapat dilihat melalui tingkat profitabilitasnya, memiliki dorongan untuk memberikan pengungkapan yang lebih luas untuk memperlihatkan kualitas perusahaannya yang lebih baik. Jadi perusahaan yang memiliki profitabilitas tinggi menunjukan kinerja keuangan perusahaan dalam kondisi baik. Kondisi tersebut akan mendorong manajemen perusahaan cenderung lebih banyak mengungkapkan informasi dalam laporan tahunan salah satunya terkait kinerja keuangan yang telah dicapai perusahaan untuk memberikan informasi kepada investor atau stakeholders terkait kondisi kinerja perusahaan.

Hasil penelitian menunjukkan profitabilitas berpengaruh terhadap pengungkapan wajib laporan tahunan pada perusahaan pertambangan periode 2013-2017. Penelitian ini sesuai dengan penelitian yang dilakukan oleh Fitri (2012) menyatakan bahwa profitabilitas berpengaruh positif terhadap pengungkapan laporan keuangan tahunan. Akan tetapi penelitian ini tidak sesuai dengan penelitian yang dilakukan oleh Juhmani (2013) menyatakan profitabilitas berpengaruh negatif terhadap pengungkapan informasi. Jadi semakin tinggi profitabilitas, maka semakin luas pula pengungkapan wajib laporan tahunan yang dilakukan.

\section{SIMPULAN}

Ukuran perusahaan, umur perusahaan dan profitabiltas berpengaruh terhadap pengungkapan wajib laporan tahunan pada perusahaan pertambangan yang terdaftar di Bursa Efek Indonesia periode 2013-2017, sedangkan struktur kepemilikan tidak berpengaruh terhadap pengungkapan wajib laporan tahunan pada perusahaan pertambangan yang terdaftar di Bursa Efek Indonesia periode 2013-2017.

\section{DAFTAR PUSTAKA}

Arif, A. (2006). Analisis Pengaruh Rasio Leverage, Rasio Likuiditas, Rasio Profitabilitas, Porsi Saham Publik, dan Umur Perusahaan terhadap Kelengkapan Pengungkapan Laporan Keuangan pada Perusahaan Manufaktur yang terdaftar di BEJ. Jurnal Informasi, Perpajakan, Akuntansi dan Keuangan Publik. 1(2), $119-133$.

Azaria, A. (2014). Faktor-Faktor Yang Mempengaruhi Tingkat Keluasan Pengungkapan Informasi Dalam Laporan Tahunan (Studi Pada Perusahaan Manufaktur Yang Terdaftar Di Bursa Efek Indonesia). Universitas Muhammadiyah Surakarta. 
Bhayani, S. (2012). The Relationship between Comprehensiveness of Corporate Disclosure and Firm Characteristics in India. Asia-Pacific Finance and Accounting Review, 1(1), pp: 52-66.

Brigham, F., E \& Joel F., H. (2010). Dasar-Dasar Manajemen Keuangan: Assetials of Financial Management. Salemba Empat. Jakarta.

Darmadji, T. \& Fakhruddin, H., M. (2012). Pasar Modal Indonesia. Edisi Ketiga. Salemba Empat. Jakarta.

Efrata, C \& Erly., S. (2012). Analisis Faktor-Faktor Yang Mempengaruhi Tingkat Keluasan Pengungkapan Informasi Dalam Laporan Tahunan. Jurnal Akuntansi. Universitas Widyatama Bandung.

Fitri, Y. (2012). Pengaruh Manajemen Laba, Likuiditas dan Profitabilitas terhadap Tingkat Pengungkapan Laporan Keuangan Tahunan. Jurnal Ilmiah Sarjana Ekonomi Jurusan Akuntansi Fakultas Ekonomi Universitas Negeri Padang.

Gayatri, I. A. Sri I. D. \& Dharma, S. (2013). Pengaruh Corporate Governance, Ukuran Perusahaan, dan Leverage terhadap Integritas Laporan Keuangan. E-Jurnal Akuntansi. Universitas Udayana.

Juhmani, O. (2013). Ownership Structure and Corporate Voluntary Disclosure: Evidence from Bahrain. International Journal of Accounting and Financial Reporting, 3(2).

Kasmir. (2014). Bank dan Lembaga Keuangan Lainnya. Edisi Revisi, Cetakan Keempatbelas. PT. RajaGrafindo Persada. Jakarta.

Maryam. (2012). Pengaruh Karakteristik Perusahaan Terhadap Keberadaan Pengungkapan Dalam Laporan Tahunan Sektor Properti Yang Terdaftar Di Bursa Efek Indonesia. Jurnal Akuntansi, 2(1), 86- 99

Murcia, F., D., R \& Ariovaldo, D., S. (2010). Determinants of Corporate Voluntary Disclosure in Brazil. Journal of International Business Studies. 2(1), 234-278

Nordiansyah, E. (2015). Diversifikasi Sumber Dana Demi Pertumbuhan Ekonomi di 2016.

Rahmawati. (2012). Teori Akuntansi Keuangan. Graha Ilmu. Yogyakarta.

Retnoningsih. (2013). Analisis Faktor-Faktor yang Mempengaruhi Luas Pengungkapan Laporan Tahunan (Studi Empiris pada Perusahaan Manufaktur yang Listing di Bursa Efek Indonesia Periode 2009-2011). Universitas Negeri Yogyakarta.

Riyanto, B. (2008). Dasar-dasar Pembelanjaan Perusahaan. Edisi Keempat. Yogyakarta: Penerbit BPFE.

Sartono, A. (2012). Manajemen Keuangan Teori dan Aplikasi. Edisi Keempat. BPFE. Yogyakarta.

Sudana. (2011). Manajemen Keuangan Perusahaan Teori dan Praktik. Erlangga. Jakarta.

Sugiarto. (2009). Struktur Modal, Struktur Kepemilikan Perusahaan, Permasalahan Keagenan dan Informasi Asimetri. Edisi Pertama. Yogyakarta:Graha Ilmu.

Sugiono, L., P \& Jogi, C. (2013). Analisa Faktor Yang Mempengaruhi Likuiditas Pada Industri Ritel Yang Terdaftar Pada Bursa 59 Efek Indonesia Tahun 2007-2012. Jurnal Business Accounting Review, 1(2), 298-305.

Suwardjono. (2014). Teori Akuntansi Perekayasaan Pelaporan Keuangan. Edisi Ketiga Cetakan Kedelapan. BPFE. Yogyakarta.

Syafi'I, I. (2013). Karakteristik Perusahaan Dan Struktur Modal Pada Perusahaan Sektor Makanan-Minuman. Media Mahardika. 
Ulum, I. (2009). Intellectual Capital: Konsep dan Kajian Empiris. Yogyakarta: Graha Ilmu.

Wijayanti, N. (2009). Pengaruh Profitabilitas, Umur Perusahaan, Ukuran Perusahaan, dan Kepemilikan Publik terhadap Ketepatan Waktu Pelaporan Keuangan. Universitas Sebelas Maret. Surakarta. 